\title{
ARTICLES
}

\section{Logic, Art and Argument ${ }^{1}$}

\section{LEO GROARKE Wilfrid Laurier University}

Abstract: Most informal logic texts and articles assume a verbal account of reasoning which defines "argument" as a set of sentences. The present paper broadens this definition in order to account for "visual arguments" which are communicated with nonverbal visual images. Standard approaches to verbal arguments are extended in a way that allows them to explain and evaluate visual argumentation.
Résumé: La plupart des manuels et articles de logique non formelle présentent le raisonnement comme une forme verbal dans laquelle un argument se définit comme un ensemble de phrases. Cet article elargit cette définition pour rendre compte des "arguments visuels" communiqués par les innages visuelles non verbales. On élargit les approches courantes de l'argument verbal de manière à leur permettre d'expliquer et d'évaluer les arguments visuels.

Keywords: Argument, argumentation theory, visual argument, art, photography, advertising, visual equivocation, logic, informal logic.

Most informal logic texts and articles still assume a verbal account of reasoning. It defines an "argument" as a set of sentences. ${ }^{2}$ In the present paper I broaden this definition to take account of "visual" arguments which are communicated with non-verbal visual images. ${ }^{3}$ I argue that doing so greatly strengthens informal logic's ability to explain and assess ordinary reasoning.

In proposing an account of visual argument I follow the lead of many authors who have recognized the importance of visual images in everyday discourse and debate. ${ }^{4}$ It is especially significant that recent commentators have begun to develop ways of understanding and assessing images. ${ }^{5}$ I want to do something similar, though my goal is an approach to visual argument which more explicitly employs the techniques which argumentation theories have developed in the realm of verbal argument.

The reasons why we should develop an account of visual argument are relatively straightforward, for visual components play a pivotal role in many attempts to prove, convince or persuade. As Barwise and Etchmendy point out, this is true even in the case of formal deductive inferences, which frequently depend on visual rather than verbal modes of reasoning. ${ }^{6}$ Visual appeals are especially pervasive in everyday discourse, in which visual images propound a point of view in magazines, advertising, film, television, multi-media, and the World Wide Web. 
Visual arguments are popular because visual images can be extraordinarily powerful. As Freedberg writes in The Power of Images: "People are sexually aroused by pictures and sculptures; they ... mutilate them, kiss them, cry before them, and go on journeys to them; they are calmed by them, stirred by them, and incited to revolt. They ... expect to be elevated by them, and are moved to the highest levels of empathy and fear. They do so in societies we call primitive and in modern societies; in East and West, in Africa, America, Asia, and in Europe." "7

Visual arguments harness the "power of images" and can, in view of this, be a very effective means of public debate. According to S.I. Hayakawa, the most influential figure in the "general semantics" movement, the visual is more powerful than the verbal. ${ }^{8}$ Whether one accepts this or not, many examples show that public opinion is increasingly determined by visual images. Morello, Jamieson, and Birdsell have, for example, shown how implicit and explicit visual arguments played a central and sometimes decisive role in the 1984, 1988 and 1992 American presidential elections. ${ }^{9}$ Morello's study of the Mondale-Reagan debates led him to the conclusion that "judgments of winners and losers [of the debates] may rest on factors having little to do with what the candidates said or did and more to do with what television shots occurred." Costanzo reaches similar conclusions in "Reading Ollie North," as does Gerbner in his study of media reports on the Persian Gulf War. ${ }^{12}$ The increasing use of visual persuasion in debates about abortion has been documented and discussed by Pickering and Lake. ${ }^{13}$

The pedagogical questions which are raised by the prevalence of visual attempts to convince are discussed by Rutledge, who notes that "the media have created an imbalance between professional persuaders and a public untrained in evaluating visual persuasion." She concludes that "we need systematic methods for training students to detect, analyze and evaluate visual images." the same point, ${ }^{15}$ but informal logic continues to virtually ignore the visual elements within everyday examples of argument. As Langsdorf puts it, we "remain curiously unaware of the need for strategies of visual literacy" which would enable us to think critically about visual texts "in a manner analogous to informal logic's critical stance toward oral and written texts." 16

One barrier that has blocked the attempt to incorporate the visual within theories of informal logic is the common prejudice that the visual and the verbal are irreconcilably distinct. As Mitchell puts it, "The realms of language and imagery, like Lessing's poetry and painting, or Kant's time and space, are generally regarded as fundamentally different modes of expression, representation and cognition." sumes this point of view, it is natural to assume that the assessment of the visual will require an approach which lies beyond standard theories of argumentation, for they have been developed to address and assess verbal forms of argument.

Fox notes many variants of the view that the visual and the verbal are irreconcilable in his overview of the literature on images. Allender, for example, holds that images challenge "ordinary logic"; Postman "believes that we do not have any tools to 
help us combat the 'seductions' of imagery, as opposed to language, where we wield logic and thetoric to help us combat the seductions of words"; and Paglia claims that "watching television has nothing at all to do with thinking and analyzing."18 Such views might easily be paired with Gilbert's suggestion that informal logic must deal with non-verbal arguments by adopting varieties of analysis which reject the linear, discursive model of rationality that it assumes. ${ }^{19}$

A discussion of such views is beyond the scope of the present paper but their prevalence demands some comment. Usually it is said that visual images are fundamentally distinct from words and sentences because they are more emotional, more ambiguous and less precise. Even if this is true, it is a mistake to conclude that visual images are instruments of persuasion which must be distinguished from arguments, which are understood as attempts to rationally convince. Even if one accepts some version of the persuade/convince distinction this implies, there are many reasons why it cannot drive a wedge between the verbal and the visual. Four of them merit quick mention.

1. Persuasion and the non-logical "exhortation" it encompasses are, as Whately and Perelman stress, an important feature of verbal argument. ${ }^{20}$ Persuasion is not, in view of this, unique to visual argument. A variety of ways of assessing it- by studying audience, for example - are, therefore, an integral part of theories of verbal argument.

2. The emotion and indefiniteness associated with visual images-as opposed to words - have been exaggerated. It is too easily forgotten that one of the prime difficulties one faces in dealing with verbal claims is vagueness, ambiguity and emotional language (something that is immediately evident when one looks at everyday arguments about issues like abortion, nuclear war, gay rights, etc.). In contrast, the meaning of many visual images-maps, pointed cartoons, paintings, etc. —can be precise, definite and or unemotional. The examples below will illustrate this point.

3. The implicitness which we associate with visual persuasion has an analogue in implicit (or "hidden") premises and conclusions that accompany many verbal claims. McMurtry has maintained that the most significant verbal arguments are implicit. ${ }^{21}$

4. Visual arguments can, as we shall see, contain a premise-conclusion structure which is amenable to standard forms of argumentative analysis. Visual arguments can, therefore, be judged by common standards of reasoned convincing, and in this way transcend the bounds of mere persuasion.

Though argumentation theory has been slow to develop the point, many empirical studies of the visual tacitly imply that the chasm which is so often assumed to separate the logic of the verbal and the visual has been greatly exaggerated. The studies in Fox's important anthology show, for example, that images are "rhetorical in nature;"22 Hovanec and Freund classify particular images as instances of fallacies; ${ }^{23}$ Dyer explains how meanings which can be understood verbally are communicated in an adver- 
tisement; ${ }^{24}$ and the analyses offered by Goldman ${ }^{25}$, Marchand ${ }^{26}$ and Williamson ${ }^{27} \mathrm{im}$ ply (even when they stress the differences between verbal and visual communication) that it is possible to explicate verbally the meaning of a visual image.

According to the account offered here, the common complaint that visual imagery promotes entertainment and persuasion over logical analysis ${ }^{28}$ reflects a failure to adapt logical tools to visual contexts rather than the inherent nature of visual images themselves. As Herb Karl suggests, there is "reason to argue that a common ground -a kind of unified field theory of meaning making that holds for language and visual images-is worth considering. ${ }^{29}$

An account of visual argument must be founded on a prior recognition of the possibility of visual statements. An example that can illustrate this possibility is the Elkanah Tisdale cartoon reproduced below ${ }^{30}$ which is a comment on Governor Elbridge Gerry's partisan restructuring of Boston's suburban electoral districts in 1812. Tisdale protested this restructuring by depicting a map of the new Boston districts in a shape he described as "a newly discovered monster, the salamander-like Gerry-mander." His cartoon is the origin of our word "gerrymandering," which similarly refers to the practice of arranging electoral districts to unfairly favour one's own political interests. His drawing clearly states that there is something sinister (indeed 'monstrous') about Governer Gerry's rearrangement of Boston neighbourhoods.

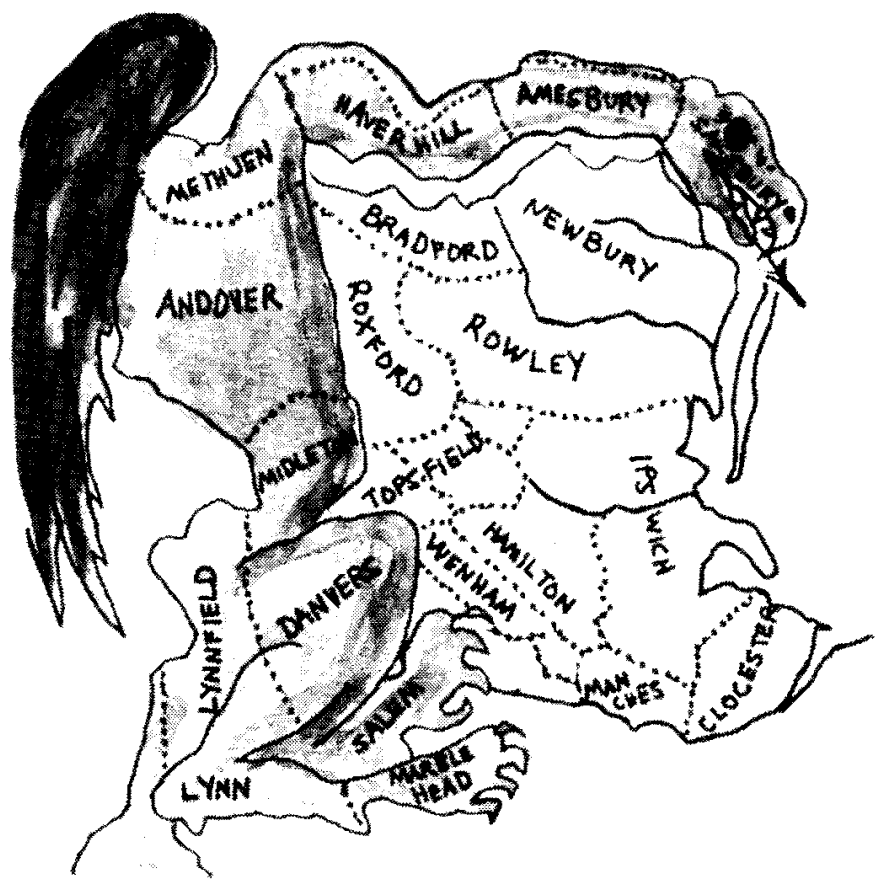

The ability to make a statement with an image explains the existence of political cartoons, which function as a standard means of social and political commentary. 
Taken as a genre, they themselves show that visual statements play a significant role in public discourse. One might usefully study the way in which they communicate a statement, but a detailed discussion of such matters is a topic for another paper. In the present context, it is enough to say that we understand the visual claims that cartoons make, though poorly constructed cartoons can, like verbal claims, suffer from vagueness and ambiguity. Suffice it to say, we can clarify visual meaning much as we clarify verbal meaning - by defining visual (as opposed to verbal) vocabulary, by discussing a statement's context, and so on.

Though most commentators recognize the possibility of visual statements, visual negations are commonly said to be impossible. ${ }^{31}$ The claim that this is so is founded on a view of visual images that treats them as no more than literal depictions of what they represent. This overlooks the conventions that implicitly govern most skillful images, which allow the creator of an image to convey a negation by invoking visual symbols for negation, by juxtaposing incongruent images or incongruent images and words, or by obviously violating or inverting standard visual conventions.

Most obviously, we can use a (usually red) circle with a diagonal as a visual negation sign. Imposed over a drawing of a burning cigarette, it conveys the message that "Smoking is not permitted." More creative uses of this version of the null symbol apply it in unusual contexts. In the midst of the MX missile controversy, for example, protest posters and buttons expressed opposition to the missile by imposing it over photographs of the missile. Here the visual negation sign allows one to convey without a verbal negation the proposed claim that the United States should not develop the MX.

In other cases, visual negations employ more complex and more fluid visual symbols. Many commentators have noted that beauty and attractiveness are often used in visuals to express approval. As Gerald Grow writes, "The beauty of the fashion model is more than a matter of looks; it represents a choice of values; it embodies, expresses, and advocates those values...." 32 The same principle operates in reverse in many visual negations, which express disapproval, rejection and negation by portraying persons and situations as ugly, impossible, insignificant or misguided.

In a cartoon entitled "Activities of a German diplomatist in America," Rogers draws Uncle Sam in a harness with blinders to make the point that the United States does not see that it is being manipulated by Germany..$^{33}$ In 1919, Boardman Robinson conveys the notion that the Treaty of Versailles will not hold by depicting the signatory pen in an emaciated dying hand, by placing a bird of prey in an ominous grey background, and by drawing a mouse nibbling at the comer of the treaty. ${ }^{34}$

The use of physical incongruities to convey visual negations is particularly common. In a nineteenth century lithograph entitled "The New Aerodynamics," Daumier suggests that European peace is not stable because it rests on armament by drawing Peace as an allegorical figure resting impossibly on the point of a bayonet (below ${ }^{35}$ ). In 1916, Boardman Russell invokes the image of an impending fall to convey the proposition that Europe does not understand the consequences of military conflict, 


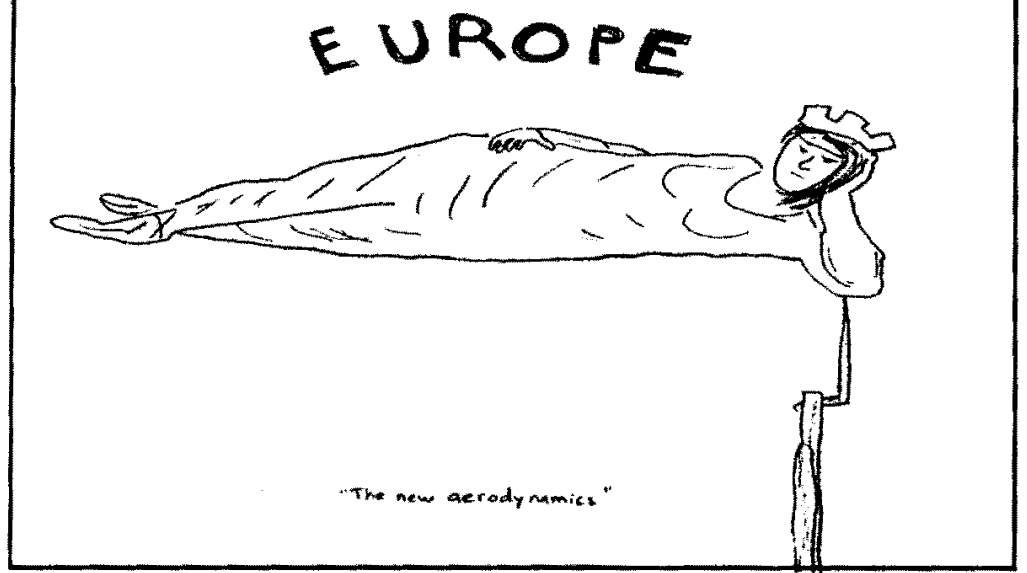

by drawing it as a braying donkey which is pursuing a juicy carrot labelled "VICTORY" over the edge of a precipice (below) ${ }^{36}$ A third example which employs the same iconography is a Herbert Johnson cartoon which suggests that the American government does not understand the precariousness of its debt situation, by depicting it as a hugely obese woman unwittingly stepping into deep waters labelled "billions of dollars of debt." ${ }^{237}$

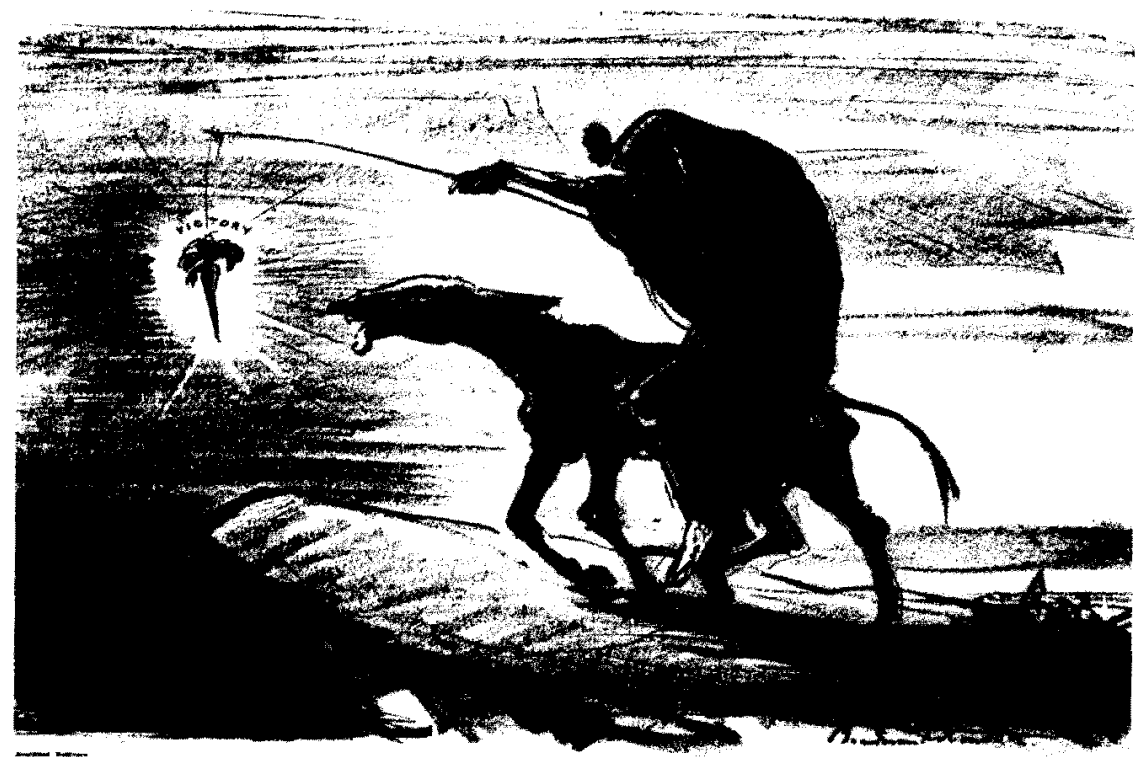

EUROPE, 1916 
In other cases, visual negations depend upon the juxtaposition of contradictory symbols, often opposing the verbal and the visual. When Daumier wishes to refute romantic notions of the victorious soldier, he draws a picture of a debauched soldier holding a bottle of wine and a whip (a frightened woman runs away from him with her baby). ${ }^{38}$ To underscore his point, he gives the piece the grand title "The Conqueror," the dissonance between the verbal message and the gritty representative soldier he has drawn declaring that a victorious army is not composed of moral heroes. ${ }^{39}$

Keeping in mind the possibility of visual assertions and negations, the next step toward a theory of visual argument is a recognition that a concatenation of visual statements in a particular image can, like a collection of verbal statements, function as reasons for a conclusion. An example is a Dutch poster (reproduced on the next page ${ }^{40}$ ) which advocates opportunities for women at the University of Amsterdam. The black and white photograph that it contains presents the university's three chief administrators in front of the official entrance to the university. Especially in poster size, the photograph makes a stark impression, placing all this confident maleness in front of (visually blocking) the university's main entrance. According to the committee which commissioned the poster, it is a "statement" which effectively makes the point that "we want more women at our university" and "still have a long way to go in this regard." 41

From the point of view of logic, the poster is something more than a statement, for it visually makes the point that the University of Amsterdam's chief administrators are all men, to back the intended claim that the university needs more women. The poster thus presents the argument:

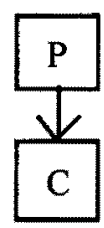

where the premise $P$ is the (visual) statement that "The University of Amsterdam's three chief administrators are all men" and $\mathrm{C}$ is the conclusion that "The university needs more women."

Other examples of visual arguments are easily found. Consider an infamous American cartoon by Art Young entitled "Freedom of the Press." 42 It depicts a newspaper office as a brothel. The newspaper editor is labelled "The Madam" and writers, reporters and staff are shown waiting to please a large well to do client labelled "Big Advertisers." The latter's pants are emblazoned with the words "RAILROADS," "DEPT STORES," "FACTORIES," "MINING COMPANIES," "BREWERIES," and soon. It is not difficult to understand Young's message: that (Conclusion) newspapers do not practise freedom of expression, for (Premises) they have no scruples and are willing to do whatever pleases their advertisers (they are, one might say, willing to "prostitute" themselves). 


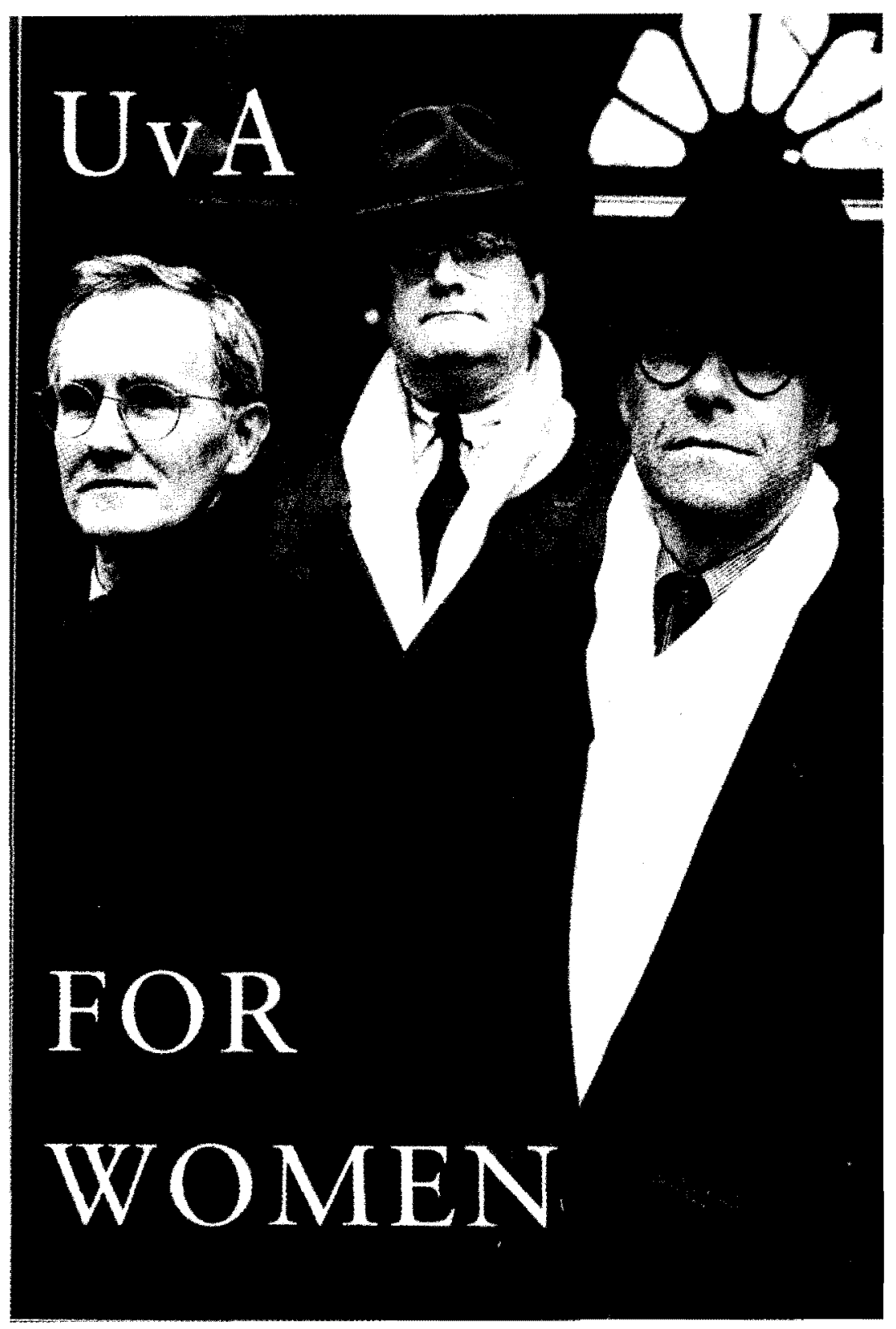


A third example of a visual argument is the following 'anti-advertisement ${ }^{43}$ produced by the Media Foundation, a Vancouver foundation which designs television and magazine advertisements designed to critique corporate advertising. ${ }^{44}$ In this case, the image is an attack on Marlboro ads which associate Marlboro cigarettes with rustic settings and the rough and rugged life of a cowboy. The skull that replaces the cowboy's face - a traditional symbol for death and disease - tells us (especially when it is viewed in tandem with the Surgeon General's Warning ${ }^{45}$ ), that Marlboros are not an ingredient of a romantic rustic lifestyle, but the cause of serious health problems. This claim backs the new caption, which is the conclusion that "You should be suspicious of Marlboro ads" (or "Don't let them rope you in").

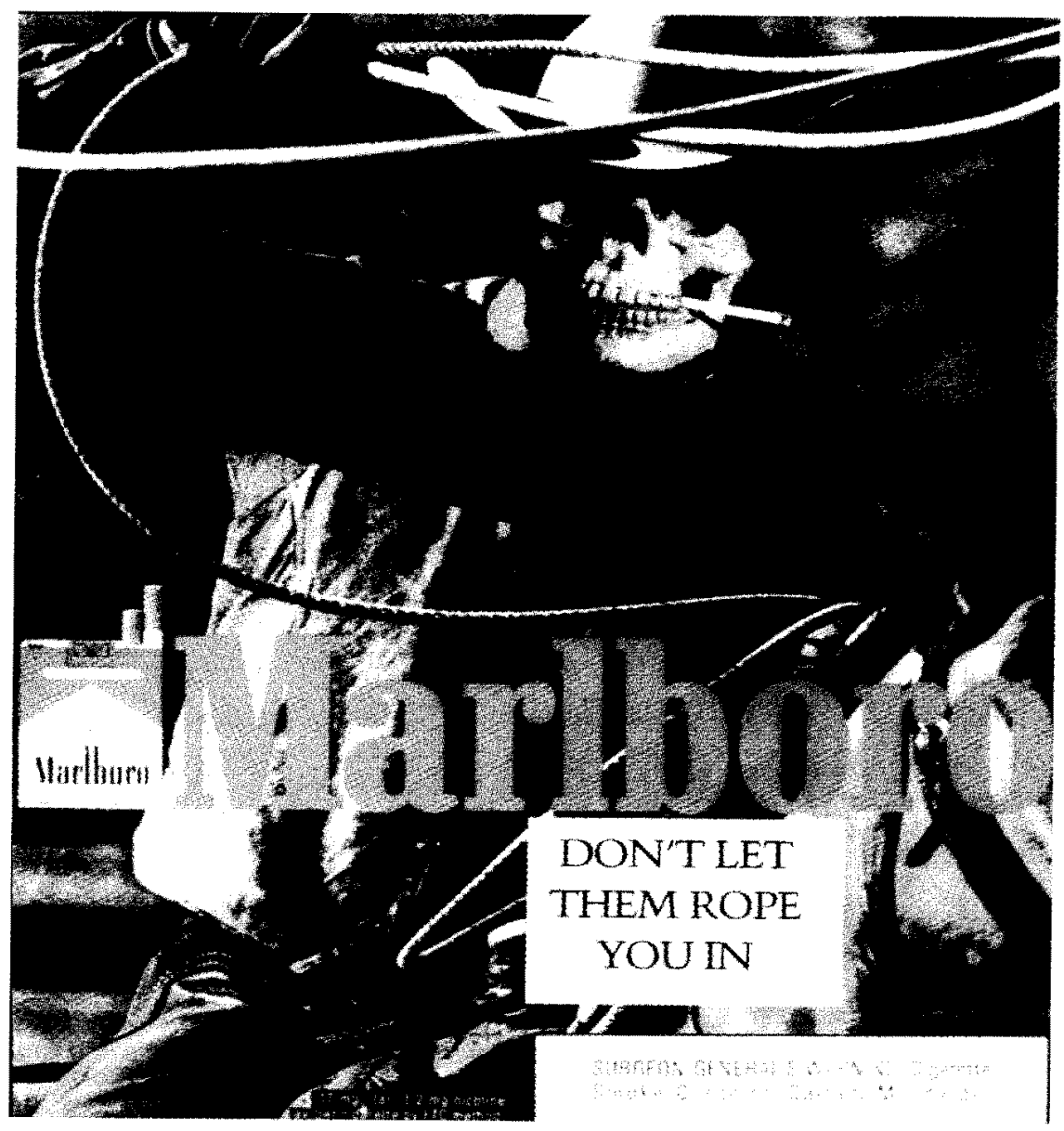

Individual visual arguments like this one often work with other arguments, forming more complex chains of reasoning. Ad campaigns are good examples, frequently functioning as extended argumentative essays in which a series of visual and/or verbal arguments work together. A good example is the Minnesota Department of Health's anti-smoking ad campaign in 1987, in which individual ads conveyed messages like 


\section{Leo Groarke}

"Smokers have bad breath," "Smoking ruins your clothes," "Smoking is expensive," "Smoking is addictive" and "Most of your peers don't smoke." Taken together, these ads represent a many-premised argument for the general conclusion that "You shouldn't smoke." Another good example is the World Wildlife Fund's extended campaign against fur (which included, among other vivid images, ads in which fur coats wom by beautiful models drip blood profusely). Fox has provided an analysis of some of the implications of advertising sequences in his account of "United Colors of Benetton" and Donna Karan advertisements. ${ }^{46}$

Once we have identified the structure of simple and extended visual arguments we can assess them by applying well-established theories of argument developed by logicians, rhetoricians and pragma-dialecticians. Among other things, these theories raise the questions:

1. whether a visual argument's premises are acceptable;

2. whether a visual argument's conclusion follows, deductively or inductively, from its premises;

3. whether a visual argument is appropriate or effective in the context of a particular audience or a particular kind of dialogue; and

4. whether a visual argument contains a fallacy or confoms to some standard pattern of reasoning (argument by analogy, straw man reasoning, modus ponens, and so on).

The application of such standards can profoundly change the way we look at many visual images, for it allows us to respond to them with something more than aesthetic appreciation, laughter or disdain. Much more appropriately, we can recognize visual arguments as moves in argumentative exchange and respond with the kinds of critical analysis arguments require.

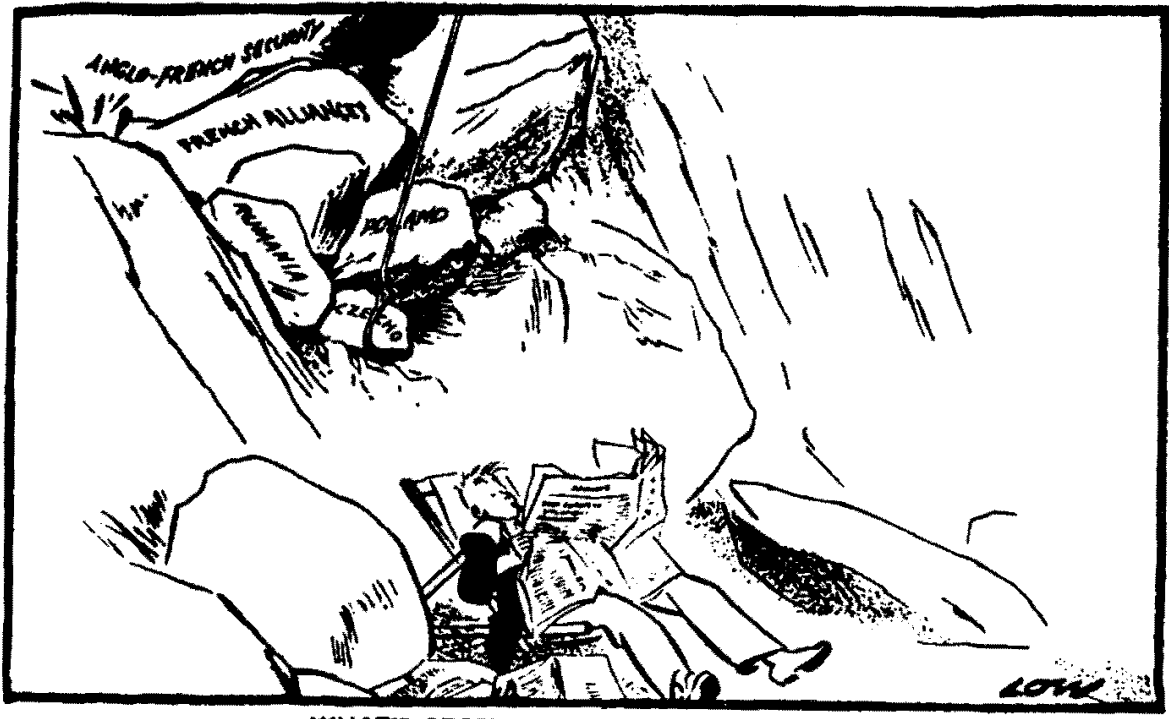

WHAT'S CZECHOSLOVAKIA TO ME, ANYWAY? 
We could usefully apply the standards of good argumentation to the examples of visual argument I have already noted (most notably, to the University of Amsterdam poster ${ }^{47}$ ), but it is more instructive to use examples that illustrate the extent to which visuals conform to standard patterns of reasoning. As a first example, consider the above David Low cartoon, published on July $18,1938{ }^{48}$ It is one of a famous series of cartoons in which Low comments on the events which precipitated World War II. In the present context, it provides a good example of a visual slippery slope argument, for it suggests that the English public's lack of concern about the Nazi's psychological war on Czechoslovakia (represented by the man in the chair, who says "What's Czechoslovakia to me anyway?') is misguided, for the fall of Czechoslovakia will initiate a chain of causes and effects that probably will precipitate the fall of Poland and Romania, the fall of the French alliances, and the consequent collapse of AngloFrench security.

The following billboard is another good example of a visual argument which conforms to standard patterns of reasoning. Posted in Toronto in 1993 to protest changes to labour laws proposed by then-Ontario Premier Bob Rae, it is a classic case of guilt by association ${ }^{49}$ for it condemns Rae's proposed reforms by associating him and his actions with Lenin, Marx and the legacy of the U.S.S.R. Like many guilt by association arguments, perhaps most, this one can be critiqued by questioning the association it is founded on. ${ }^{50}$

\section{IT DIDN'T WORK IN THE U.S.S.R.}
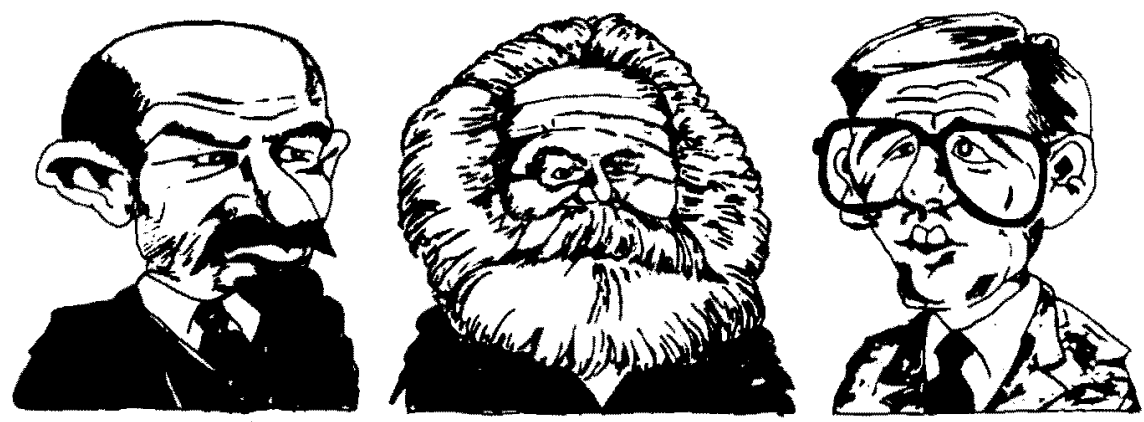

WHY ONTARIO BOB? 


\section{Leo Groarke}

The extent to which visual discourse naturally incorporates standard argumentative moves is seen in the following $1926 \mathrm{~K}$.A. Suvanto cartoon entitled "The Model and the Painting." It It critiques then popular attacks on communism which argue that the Soviet Union was blood-thirsty and repressive. Suvanto portrays such detractors as affluent capitalists (obesity being the standard sign of capitalism) and accuses them of straw man reasoning. Their alleged misrepresentation is clear in the painting inside the cartoon, which pictures a Soviet worker as a brutal killer who holds a bloodstained knife raised above an intended victim. The Soviet flag is in the process transformed into a skull and cross-bones.

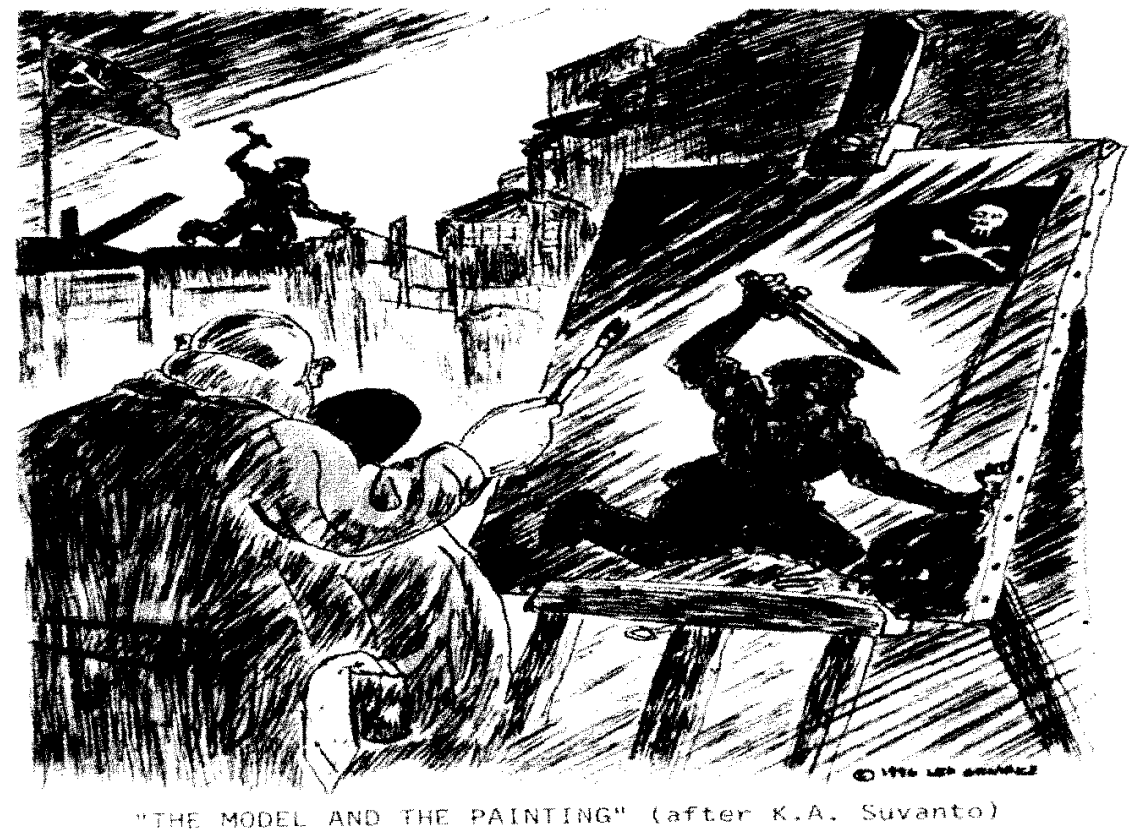

Another fallacy which merits attention in visual dialectic is a visual version of equivocation. In verbal arguments equivocation depends on verbal ambiguity. In visual arguments it depends on visual ambiguities which are similarly exploited. Usually, this is done by conflating moral and aesthetic values, promoting the view that a person, policy or action is morally good or bad (or beautiful, ugly, disturbing, reassuring, etc.) by appealing to visual images which shows them as aesthetically good or bad (beautiful, ugly, etc.).

Robert Litke presents a good example of "visual equivocation" in a forthcoming article on the Sierra Club's campaign against clearcut logging. ${ }^{52}$ He focuses on the main vehicle for the campaign, which is a coffee table book which emphasizes large glossy photographs of the aftermath of clear cutting. ${ }^{53}$ The photos are stunning, espe- 
cially when the authors provide a "before" and "after" photo. Before, one sees lush foliage and verdant greens. After, one sees a scarred grey landscape dominated by broken tree stumps and lifeless broken branches. The very negative view of clearcutting that emerges is reinforced by text which includes claims like: "Clearcuts are ugly. People who see them, even children, know instinctively that they are wrong, an outrage, a sacrilege." and "If logging looks bad, it is bad. If a forest appears to be mismanaged, it is mismanaged." 54

This is not the place to decide whether clearcuts are bad forestry, though it should be said that this is a controversial claim. According to many experts, clearcuts can aid forest renewal, in much the way that fires and naturally occurring disasters have promoted it in the past. The important point is that one cannot prove one view or the other simply by showing that clearcuts look bad or ugly. As Litke points out, a mastectomy or a kidney operation does not 'look' attractive but this does not make it bad medicine. He convicts the Sierra Club of verbal equivocation for conflating moral and aesthetic judgments of good and bad to make its point.

Another notable example of visual equivocation occurred in the 1994 Canadian federal election. In an attempt to reverse a dramatic slide in popularity, the Conservative Party launched an "attack" campaign against Jean Chretien, the leader of the Liberals. ${ }^{55}$ The television advertisements used in the campaign featured large unflattering close-ups of the Liberal leader speaking. They make him look extremely odd and awkward because his face is partially paralysed. The video footage is accompanied by a voice which asks the question "Would you want this man to be your Prime Minister?" The question is obviously rhetorical. The intended answer-"You do not want this man to be your Prime Minister"- -is supported by the visuals, which show Chretien to be clumsy, odd and awkward. The problem is that they show this in an irrelevant sense, conflating looking clumsy, odd and awkward with being clumsy, odd and awkward in a sense which would prevent him acting as a good Prime Minister.

Fallacy theory explains why the visual attacks on Jean Chretien were poor arguments. Rhetorical theories of argument better explain why the ads were so unsuccessful, drawing widespread criticism and damaging rather than helping the Conservative campaign. The Conservatives would have done well to heed Aristotle's comments on ethos in his Rhetoric, where he writes that: "Persuasion is achieved by the speaker's personal character (ethos) when the speech is so spoken as to make us think the speaker credible. We believe good people ...." Instead of respecting this principle and arguing in a way that established their own credibility, the Conservatives used a malicious ad hominem attack that seems to imply prejudice against the physically disabled. In the process they persuaded the Canadian public that they, rather than Chretien, lacked credibility.

Visual equivocation is a useful fallacy because it is a frequent feature of visual debate. It is the root problem in many of the visuals which Fox uses to illustrate "the skilfully manipulated ambiguity of images, for which we are easy prey" (though he mistakenly maintains that there is no verbal analogue).$^{57}$ Critical thinkers must keep 


\section{Leo Groarke}

the possibility of visual equivocation in mind when confronted with powerful images of bloodied fetuses, or dead women, in arguments for or against legalized abortion; when campaigns against seal hunting emphasize visuals which feature the clubbing of baby seals; and when lawyers in highly publicized trials like the O.J. Simpson trial orchestrate proceedings to make their clients "look" innocent and upright. ${ }^{58}$

In complex visual arguments, visual equivocation is often used in conjunction with other argumentative techniques. I want to demonstrate the complexity of some visual images with examples from the world of art. In doing so, I do not want to exaggerate the extent to which art can be argument. There is something right about the suggestion that the Sistine Chapel is great art, and that this is true whether or not we can interpret and assess it as a good (or bad) argument on the relationship between God and man. It goes without saying that many, perhaps most, works of art do not function as statements, arguments, or attempts at persuasion. More deeply, art may defy verbal interpretation for a variety of reasons: because it is purposely open-ended, because it is not intended as a comment on the world beyond it, because it emphasizes visual properties that are difficult to verbalize, and so on.

This being said, it would be a mistake to reject carte blanche all attempts to subject a piece of art to argumentative analysis. In many cases, works of art are explicitly created for the purposes of advocacy or reflection, and function as a way to make a statement or convince an audience of a particular point of view. A useful example is a famous John Heartfield photomontage which has as its subject the Nazi leader Goering. ${ }^{59}$ It is a disturbing but truthful work which portrays Goering as a butcher. He is shown yelling with a butcher's apron wrapped around his Nazi uniform. In his right hand he clutches a butcher's cleaver which extends beyond the border of the photograph. It and the apron are bespeckled in blood. The statement that the work makes that Goering is a butcher - is obviously intended as a contribution to political debate. Because it is a statement it can be assessed in much the way we might assess verbal statements in argumentative exchange. In this case we might say that the work makes a statement which is true, significant and courageous. ${ }^{60}$ The statement is so much a part of the work that it seems impossible to discard it, even when we want to consider the piece from an aesthetic point of view. To think otherwise is to artificially separate aesthetics, politics and argumentative exchange in a work in which they are inseparable.

In this and many other cases, one might argue that works of art are great works-at least in part-because of the statements or arguments they convey. Grosz's disturbing drawings on war are difficult to defend as formal masterpieces. What is great about them is their blunt and profound statements about the inhumanity of war; statements that combine to make a detailed case against it.

If this is correct, then the argumentative aspects of many works of art show that a purely formal aesthetics is too limited ${ }^{61}$ though it is important to say that we can usefully analyze art as argument even if one retains formalism. For even in this case, it must be admitted that many art works function as something more than purely aes- 
thetic objects-for many of them function as works of social commentary, propaganda, philosophical reflection, and so on. It follows that argumentation theory can tell us something interesting about particular works of art, even if this is something that takes us beyond aesthetics.

I want to illustrate the way in which argumentative analysis can illuminate a work of visual art by turning first to Jaques Louis David's 1793 painting The Death of Marat (La mort de Marat, below ${ }^{62}$ ). It is a magnificent "painterly display of consummate beauty,"63 but it is also a work of propaganda which was created to rouse support for the French revolution. The decision to display the painting during the French bicentennial celebrations in 1989 precipitated great controversy, French journalists protesting that it glorified a man opposed to freedom of the press and famous for "his eternal call to massacre."

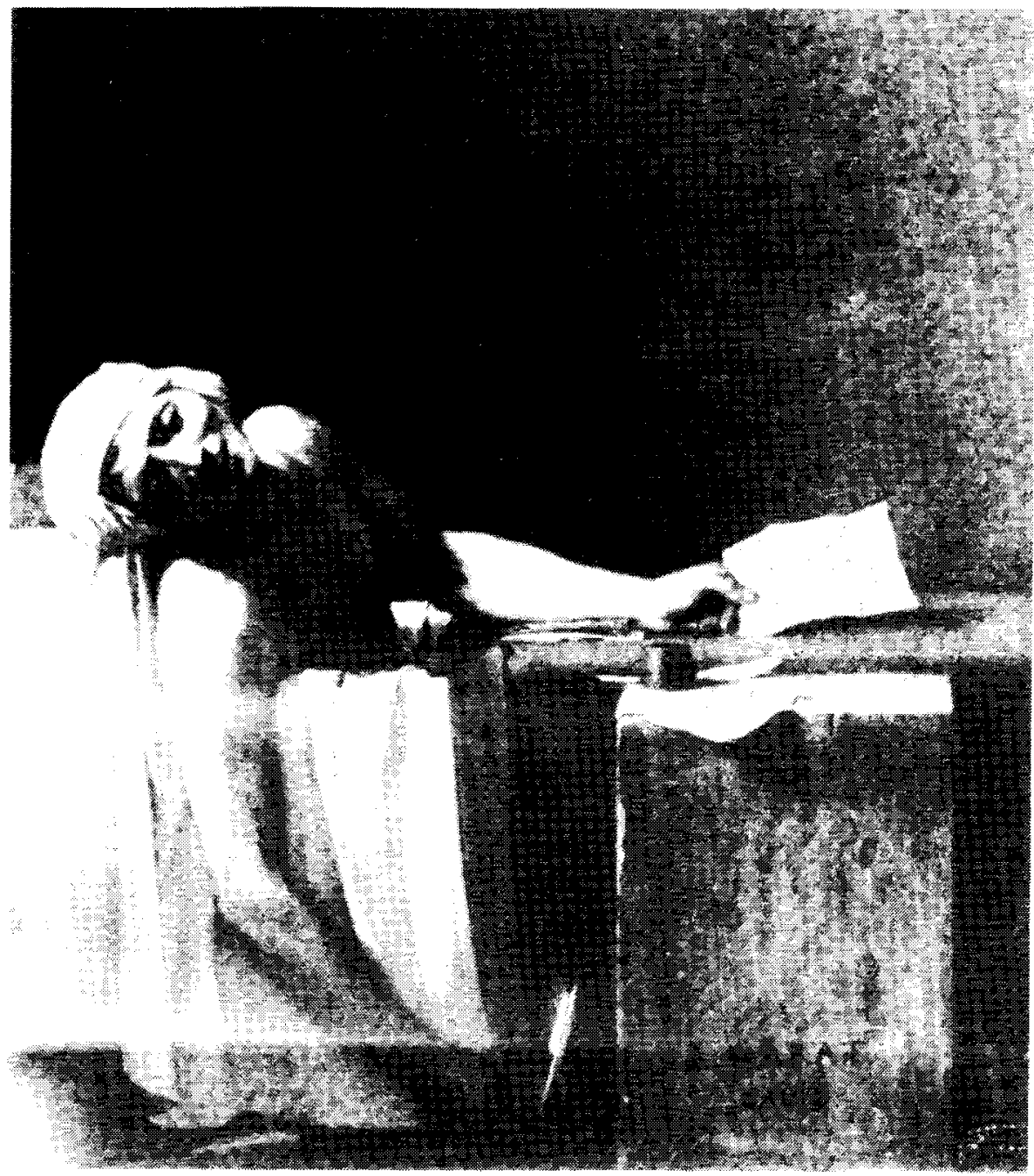


The notion that Marat is a visual argument is very much in keeping with the aesthetics of its own time, which saw art as a vehicle for "the edification and uplifting of mankind." "6s As a painter, David was famous for "historical painting," which attempted to use painting as a way of teaching moral lessons. ${ }^{66}$ As a proponent of the New Republic, he wanted to create works that encouraged high moral standards and patriotic self-sacrifice. ${ }^{67}$ He painted Marat for the French National Convention. In presenting the painting to its members, he told them that "your looks, in following the livid and bloody features of Marat, will remind you of his virtues, which must never cease to be yours." The implied claim that Marat's assassination made him a heroic martyr is powerfully conveyed by the stillness of the composition and the lighting, which highlights Marat's slumped figure against a dark background.

We might easily understand the message of David's painting as the argument: "Marat was a great martyr. You should, therefore, strive to be like him (and support the Revolution)." There is something to this analysis, but a fully satisfactory account of Marat must better recognize the painting's visual and political context, which are evident in a number of its details. Above all else, it is important to recognize that its style and composition compare Marat to Christ. This is in keeping with hymns and rumours of the day, which celebrated this comparison (Marat's heart was, for example, treated as a relic and claimed to resemble Christ' $\left.s^{69}\right)$. Louis Groarke writes:

David likewise presents us with a homage to a revolutionary Christ. The treatment of the figure recalls traditional religious iconography. The idealized nude body is like a Renaissance Christ. The recumbent pose with the extended, trailing arm recalls, in detail, depictions of the Disposition of Christ (cf. Girodet, Caravaggio, Montagnea, Pontormo, Fiorentino, van der Wyden, etc.). The gaping wound with the stream of blood parallels the wound in the Saviour's side. The knife, smeared with blood, is the instrument of his passion, comparable to the lance and thorns and nails emphasized in many paintings of Christ's passion. Even the note clutched in his languishing hand might be compared to the notice nailed to the cross above the Saviour's head .... Marat is presented here as the personification of virtue, a Christ-figure who gave his life, his blood for the salvation of his people. ${ }^{70}$

The comparison of Marat's and Christ's death is underscored in some of the details of the painting. Notably, the dedication " $A M A R A T$ " (TOMARAT) makes it a homage to a hero rather than a simple portrait, and the date, listed as " $L$ 'An Deux" (Year Two), makes the declaration of the French Republic, like Christ's life, an event around which time and history can be measured.

We can recognize these aspects of the painting by ascribing to it the argument "Marat was a Christ-like martyr, so you should strive to be like him in support of the Revolution." This summary well captures the essence of the piece, which is a call to emulate Marat built upon an argument from analogy which compares Marat to Christ. We can assess this argument as we assess any argument by analogy. Looked at from this point of view, it must be said that there are problems with Marat, for an argument by analogy is plausible only if there are no relevant dissimilarities which distinguish the analogues in question. This is a serious problem in the case of Marat, for Jesus' 
extreme pacifism seems virtually the opposite of Marat's role in the French revolution-a role founded on his "incessant" "bloodthirsty" calls for executions which resulted in hundreds being guillotined.

This is a useful assessment of the reasoning in Marat, but it can fairly be said that it leaves out important aspects of David's argument, for his comparison of Marat and Christ is backed by aspects of the painting we have yet to note. Consider first the alm on Marat's bedside box, which is accompanied by a promissory note that reads "You will give this assignat to this mother of 5 children whose husband died in defense of the fatherland." As this was widely believed to be Marat's accumulated wealth when he died, this detail of the painting tells its intended audience that Marat gave his last penny to the poor. The generosity this implies supports the comparison with Christ. A saintly altruism is also supported by the note from Marat's assassin (Charlotte de Corday), which appeals for an audience with him on the grounds that he is a benefactor of the unfortunate. ${ }^{71}$ Finally, a host of other details - Marat's beatific expression, his attractive looks, and the "pristine, clean, immaculate" blanket, sheet, box and bandage despite the impoverished surroundings - suggest that Marat was, like Christ, a man of great dignity and composure.

We may recognize these details of David's painting by diagramming it as the extended argument:

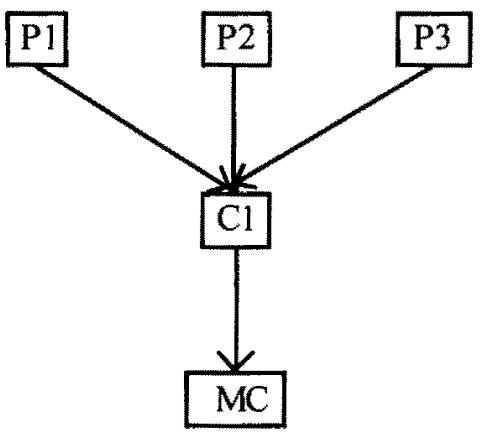

where $\mathrm{P} 1$ = Marat was a man of great dignity and composure; $\mathrm{P} 2=$ Marat's assassin herself recognized his reputation as a benefactor of the unfortunate; P3 = Marat gave his last penny to the poor; $\mathrm{Cl}=$ Marat was, like Christ, a great moral martyr; and $\mathrm{MC}$ $=$ You must strive to emulate Marat in support of the revolution.

Recognizing these further details of the painting does increase the complexity of Marat's argument, but it does not rehabilitate his reasoning. It can better be said that it compounds the problems for $\mathrm{P} 1$ and $\mathrm{P} 2$ and $\mathrm{P} 3$ are all unacceptable. The truth is that Marat was famous for his lack of dignity and composure; $;^{72}$ that an inventory of his 


\section{Leo Groarke}

possessions made when he died did not include the alm which David painted; and that the note from his assassin appealed to his reputation as a bloodthirsty executioner rather than a benefactor of the unfortunate, promising him the names of counterrevolutionaries. ${ }^{73}$ Marat's last words were said to be: "They will soon be guillotined."

These criticisms of the argument in Marat cannot undermine the fact that it displays a magnificent ability to paint. But one artificially ignores the meaning of the painting if one does not recognize that David was a social commentator as well as a painter when he created Marat. It is not insignificant that he wielded tremendous influence and contributed to out-of-control executions by propounding faulty arguments that glorified Marat. One might best compare his masterpiece to a rhetorically powerful verbal argument which is nonetheless founded on false premises and invites a faulty inference.

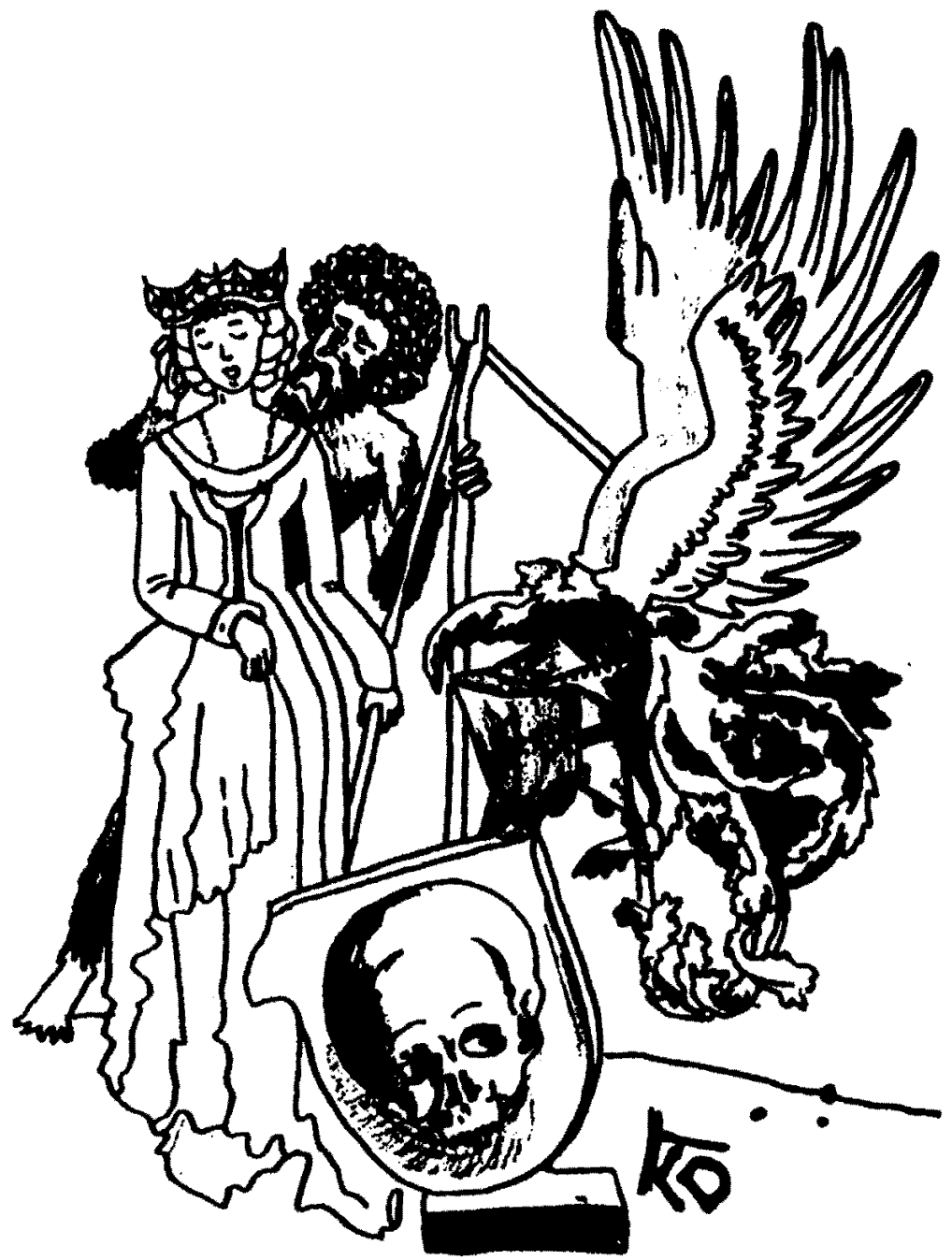


A second example which can illustrate the possibility of "art as argument" is a well-known Albrecht Dürer engraving usually called the "Coat of Arms of Death." 74 Inspired by a Northem Renaissance spirit which emphasizes the transience of life and the vanity of human pursuits, Dürer's engraving is an ingenious attempt to present such reasoning visually, in a coat of arms. Its four basic elements are sketched in the illustration on page 122. They include a bride in a sumptuous gown and crown, a wild man who stands behind her, a shield emblazoned with a skull, and a gaudy, florid helmet. The helmet and the bride represent the values which are celebrated in normal coats of arms - beauty, wealth and glory. Dürer juxtaposes them with two standard symbols for death-a wild man and a skull. The bride, whose eyes are closed, fails to see that she is really married to wild man death. The precariousness of wealth and glory is evident in the way the florid helmet is precariously balanced on the shield of death, and in the strap which makes its balance depend on the position of the wild man's staff.

The message of Dürer's engraving — that death makes beauty, wealth and glory insubstantial - is relatively uncontroversial, but it has not been recognized as the basis of an intriguing exercise in visual argument. Thus the statement that it makes provides a reason for rejecting coats of arms, which celebrate the values it critiques. Dürer's work thus functions as a visual critique of a particular artistic/visual genre, i.e., coats of arms. Given that it is a coat of arms itself, it can best be described as a visual reductio ad absurdum or an "anti-coat-of-arms." This is significant from the point of view of argument, for one might easily compare Dürer's piece to other visual and verbal reductio ad absurdums. Most interestingly, perhaps, one might compare it to philosophical attempts-by Wittgenstein and the ancient sceptics, for example- to use philosophy and argument to undermine philosophy and argument.

In the present context I want to show that this is a genre of visual argument that merits further study by comparing Dürer's work to the Powershift anti-advertisement which is our next example (see next page). ${ }^{75}$ We might summarize its message as the statement that "Advertisements mislead." Like Dürer's coat of arms, it thus functions as a visual refutation of a visual genre, in this case contemporary advertising. As it is itself an advertisement, it too can be classed as a visual reductio. As in the case of Dürer, we might ask whether its initial premise is acceptable, whether it is inconsistent, and what we should make of a secondary argument which is implied by Dürer's and Powershift's signatures. ${ }^{76}$

This is not the place to pursue these issues in detail. In the present paper I only want to demonstrate the link between important works of art and contemporary works of visual advocacy, and to show that the complexities of verbal argument often have visual analogues.

Instead of pursuing such issues in further detail, I want to finish the present paper by noting that it is in many ways limited. It does not claim that all visual images function argumentatively and does not propose a complete account of visuals that do. A more comprehensive account of visual arguments will have to be founded on case 
studies of the visual that might be compared to the studies of verbal argument which

\section{Advertising.}

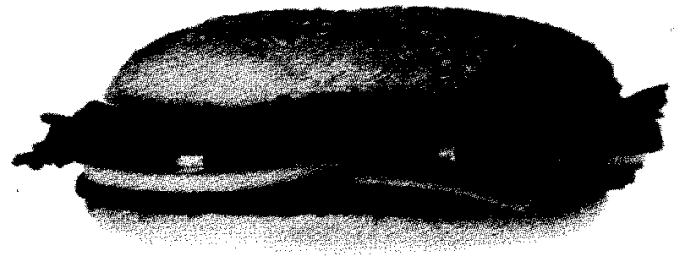

\section{Reality.}

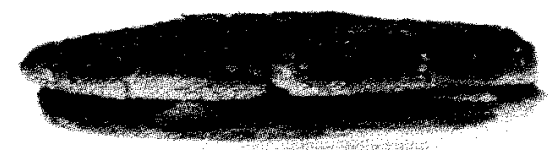

are now a commonplace in studies of argument. The most important point is that these studies must be rooted in a fundamental change in attitude that makes argumentation theorists more conscious of the visual when they discuss argumentation from both a theoretical and a practical point of view. ${ }^{77}$

In the long run, a better understanding of visual argumentation may help us better understand some facets of verbal argument. Walton, ${ }^{78}$ Blair ${ }^{79}$ and pragma-dialecticians have, for example, pointed out that verbal arguments need to be considered in the context of particular kinds of dialogue and the expectations that accompany them. Premise adequacy in a scientific paper may, for example, differ from premise adequacy in public policy debate. We may be better able to understand such differences if we study visual arguments, for they are characterized by more clearly understood distinctions between different genres (political cartoons and portraiture do not, for example, assume the same visual conventions).

This is not the place to pursue these and other issues. In the present paper, I only want to demonstrate the need to broaden our theoretical horizons and find room for visual arguments within informal logic. If we develop an account of visual arguments along the lines I have suggested - by extending the logical notions we already employ in dealing with verbal reasoning - then the theoretical cost of such analyses will be minimal, though the result will be a dramatically more powerful account of everyday reasoning, argument and debate. 


\section{NOTES}

${ }^{1}$ I am indebted to many people who contributed to the thoughts expressed in this paper. I especially want to thank Mark Vorobej, David Birdsell, Hans Hansen, Louis Groarke, Tony Blair, Lenore Langsdorf and the other Informal Logic referee.

${ }^{2}$ The verbal paradigm is, therefore, stressed in histories of informal logic. See Ralph H. Johnson and J. Anthony Blair, "Informal Logic: Past and Present" in Ralph H. Johnson and J. Anthony Blair (eds.), New Essays in Informal Logic, 1-19 (Windsor, ON: Informal Logic, 1994), and "Informal Logic in the 20th Century," in Douglas Walton and Alan Brinton (eds.), Historical Foundations of Informal Logic (Aldershot: Ashgate, 1997).

${ }^{3}$ In many cases, such arguments incorporate verbal and visual images.

4 See, for example, Roland Barthes, "Rhetoric of the Image," in Image, Text and Music, tr. Stephen Heath (Glasgow: Fontana/Collins, 1977); Martin Jay, Downcast Eyes (Berkeley: University of California Press, 1993); and W.J. Mitchell Iconology: image, text, ideology (Chicago: University of Chicago Press, 1986).

5 See, for example, the essays in Roy F. Fox's Images in Language, Media, and Mind (Urbana: National Council of Teachers of English, 1994). For a good overview, see Fox's own chapter 1, "Image Studies: An Interdisciplinary View."

" Jon Barwise and John Etchmendy, "Visual Information and Valid Reasoning," in Leslie Burkholder, (ed.), Philosophy and the Computer (Boulder: Westview Press, 1992).

7 The Power of Images: Studies in the History and Theory of Response (Chicago: The University of Chicago Press, 1989),

8 "Beyond 'The Empty Eye': A Conversation with S.I. Hayakawa and Alan R. Hayakawa," Chapter 13 in Fox, op. cit., p. 189.

"See John T. Morello, "Argument and Visual Structuring in the 1984 Mondale-Reagan Debates: The Media's Influence on the Perceptions of the Clash," Western Journal of Speech Communication, Vol. 52, 1988 (Fall); Kathleen Hall Jamieson, Dirty Politics, esp. 64-120 and 281-288 (New York: Oxford University Press, 1992); and David Birdsell, "Enthymemes in Intermediated Public Argument," in van Eemeren, Rob Grootendorst, J. Anthony Blair and Charles Willard, (eds.), Analysis and Evaluation, Vol II of the Proceedings of the Third International Conference on Argumentation (Amsterdam: SicSat, 1995).

${ }^{10}$ Morello, ibid., p. 287.

"William Constanzo, Chapter 8 in Fox, op. cit.

${ }^{12}$ George Gerbner "Instant History, Image History: Lessons from the Persian Gulf War," Chapter 9 in Fox, op. cit.

13 "Historically, images have played an important part in this controversy on both sides. Anti-abortionists have made extensive use of photographs, including smiling fetuses that suck their thumbs and the bloody, mangled remains of abortion .... For their part, pro-choice advocates have used images such as a bloody coat hanger and the Statue of Liberty to argue that abortion should remain legal .... In 1985, in 'a dramatic shift in the contest to find the most persuasive imagery" ... [the pro-life side unveiled] the 28-minute film, The Silent Scream. Since then, both sides have made increasing use of cinematic images to make their case ...." (Barbara Pickering and Randall Lake, "Refutation in Visual Argument: An Exploration," 136; in van Eemeren et al., Reconstruction and Application, Vol. III of the Proceedings of the Third International Conference on Argumentation, Amsterdam: SicSat, 1995). 
${ }^{14}$ Kay Ellen Rutledge, "Analyzing Visual Persuasion,"pp. 204-205 in Fox, op. cit. The techniques she proposes-Kenneth Burke's Pentad and Hugh Rank's schema for propaganda analysiswell complement, and to some extent, overlap the techniques I propose here.

${ }^{15}$ Carol Moog, e.g., in her discussion of sexual messages in advertising. See "Ad Images and the Stunting of Sexuality," p. 168 in Fox, op. cit.

${ }^{16}$ Lenore Langsdorf, "Dialogue, Distanciation, and Engagement: Toward a Logic of Televisual Communication,"Informal Logic, X.3, Fall 1988, p. 159.

${ }^{17}$ Mitchell, op. cit., p. 3. Cf. Suzanne Langer's views in Philosophy in a New Key: A Study in the Symbolism of Reason, Rite and Art (Columbia: University of South Carolina Press, 1987).

${ }^{18}$ Fox, op. cit., p. 15.

${ }^{19}$ Michael Gilbert, "Multi-modal Argumentation," Philosophy of the Social Sciences, Vol. 24, No. 2, June 1994.

${ }^{20}$ See Robert Whatley, Elements of Rhetoric, pp. 135-145 (Carbondale: Southern Illinois Press, 1969); and Chaim Perelman, The Realm of Rhetoric, pp. 17-18 (Notre Dame: University of Notre Dame Press, 1982).

${ }^{21}$ John McMurtry, "The Unspeakable: Understanding the System of Fallacy in the Media," Informal Logic, Vol. X, No. 3, 1988 (Fall). This discussion is unfortunately marred by McMurtry's very heavy-handed commitment to his own ideological biases.

${ }^{22}$ Fox, op. cit., p. xii.

${ }^{23}$ Carol Hovenac and David Freund, "Photographs, Writing, and Critical Thinking," Chapter 4 in Fox, op. cit.

${ }^{24}$ See, in particular, "What Do Advertisements Mean?" Chapter 5 of Gillian Dyer, Advertising as Communication (New York: Metheun, 1982).

${ }^{25}$ Robert Goldman, Reading Ads Socially (New York: Routledge, 1992).

${ }^{26}$ Roland Marchand, Advertising the American Dream (Berkeley: University of California Press, 1985).

${ }^{27}$ Judith Williamson, Decoding Advertisements: Ideology and Meaning in Advertising (Boston: Marion Boyars, 1978).

${ }^{28}$ See Costanzo in Fox, op. cit., p. 120 and Gerbner, also in Fox, pp. 125-126.

${ }^{29}$ Fox, op. cit., p. 198.

${ }^{30}$ This version is drawn by Leo Groarke. Copyright 1997, Leo Groarke.

"For a good discussion of the issue, see Pickering and Lake. They rightly want to make room for visual refutation, but there is no reason not to go the one step further and talk explicitly of visual negations.

32 "“Don't Hate Me Because I'm Beautiful'; A Commercial In Context," Chapter 13, p. 171, in Fox, op. cit.

${ }^{33}$ William Murrell, A History of American Graphic Humour, p. 194, il. 177 (New Y ork: Cooper Square Publishers, Inc, 1967, copyright 1938).

${ }^{34}$ Murrell, ibid, p. 195, il. 182.

${ }^{35}$ This illustration is a facsimile drawn by Leo Groarke which only shows the essential elements of Daumier's lithograph (copyright Leo Groarke 1997). For a reproduction of the latter, see litho \#3120. Plate 20 in Hans Rothe, Daumier on War (New York: De Capo Press, 1977).

${ }^{36}$ From The Masses, October, 1916. See Murrell, op. cit, p. 188, il. 179.

${ }^{37}$ See Murrell, op. cit., p. 255, il. 239.

${ }^{38}$ Lithograph No. 2960. Plate 34 in Rothe. 
${ }^{39}$ Other examples of this technique are included in the examples I discuss below.

${ }^{40}$ I am indebted to the Emancipation Committee for Women, University of Amsterdam, for permission to reproduce this poster.

4) Personal communication.

${ }^{42}$ The cartoon is reproduced in Leo Groarke, Christopher Tindale, and Linda Fisher, Good Reasoning Matters, p. 6 (2nd ed., Toronto: Oxford University Press, 1997). See also Murrell, op. cit., p. 180 , il. 162.

${ }^{43}$ From Adbusters, Vol.3, No.4, Summer 1995, published by the Media Foundation, 12437 th Avenue, Vancouver, B.C. V6H 1B7. Reprinted with permission.

${ }^{44}$ This is an intriguing attempt to fight fire with fire - in this case, to refute visual arguments on their own (visual) terms.

${ }^{45}$ Clearly, this is not conveyed by the waming itself; otherwise, ordinary Marlboro ads would argue against cigarette smoking.

${ }^{46}$ Fox, op. cit., pp. 79-87.

${ }^{47}$ The poster is rhetorically effective, and one cannot dispute its point that the chief administrators are all men. But some would dispute the proposed conclusion on the grounds that the number of senior male administrators is not a reasonable gauge of opportunities for women in an institution. See Leo Groarke, "What's in a Number?" and Andrew lrvine, "Jack and Jill and Affirmative Action," Dialogue: The Canadian Philosophical Review, Vol 34, No. 3, 1996 (Summer).

${ }^{48}$ This version is drawn by Jeff Cressman. Copyright Leo Groarke 1997.

49 This sketch is by Jeff Cressman and Leo Groarke. Copyright Leo Groarke 1997.

${ }^{50}$ For an account of reasoning by association, see J. Frederick Little, Leo A. Groarke \& Christopher W. Tindale, Good Reasoning Matters/270-71, (Toronto: McClelland \& Stewart, 1989).

5) This version drawn by Leo Groarke and Jeff Cressman. For a copy of the original, see Murrell, ap. cit., p. 218 , pl. 201.

${ }^{52}$ Robert Litke, "Clearcut: A Case Study," forthcoming.

${ }^{53}$ Clearcut (Earth Island Press, 1993).

${ }^{54} \mathrm{Pp} .41,64$.

${ }^{35}$ For a good overview of the ad campaign and its failure, see Kenneth Whyte, "The Face that Sank a Thousand Tories," Saturday Night, Vol. 109, No. 2, (February 1994).

${ }^{56}$ Rhetoric, 1356al-14 (tr. by Roberts).

${ }^{5}$ Fox, op. cit., p. 70 .

${ }^{58}$ An example: in the pretrial proceedings for the O.J. Simpson murder trial, the most televised trial in American history, it was said that the defense changed seating at the defense table to purposely place an attractive young legal assistant next to Simpson, associating him on television with this attractive woman.

${ }^{9}$ For a print, see p.432, il. 10.32 in Robert Bersson, Worlds of Art (Mountain View: Mayfield, 1991).

60urage (and significance) is not a logical property, but it is nonetheless a property of some argumentative moves and not others. Judgments of this sort are, therefore, a legitimate part of argumentative analysis.

${ }^{61}$ Of the sort propounded by, e.g., Clive Bell, Art (New York: Capricorn Books, 1958); Roger Fry, Vision and Design (Middlesex: Penguin, 1961); and Clement Greenberg, The Collected Essays (Chicago: University of Chicago Press, 1986). 
${ }^{62}$ Unfortunately, it is difficult to appreciate the force of the painting in this black and white print (taken from Elie Faure, Modern Art, Vol. IV of A History of Art; Garden City; Garden City Publishing, 1924). For a superb high quality reproduction see Antoine Schnapper, David (New York: Alpine Fine Arts, 1982), pl. 93, p. 158. For another discussion of the painting complete with colour plate, see Luc de Nanteuil, David (London: Thames and Hudson, 1990), colorplate 17, p. 80.

${ }^{63}$ Louis Groarke, "David's Marat: Beautiful Falsity or False Beauty?" forthcoming.

${ }^{64}$ Henri Béraud, Twelve Portraits of the French Revolution (Boston: Little, Brown and Company, 1928), p. 122.

${ }^{65}$ Diane Kelder, Aspects of 'Official Painting' and Philosophic Art, 34 (New York: Garland Publishing, 1976).

${ }^{66}$ Louis Groarke, op. cit., p. 21.

${ }^{67} \mathrm{Ibid}$, p. 24.

68 Anotoine Schnapper, David, 158 (New York: Alpine Fine Arts, 1980).

${ }^{6}$ Béraud, op. cit., p.131.

${ }^{70}$ Louis Groarke, op. cit., p. 27.

${ }^{71}$ The note from his assassin reads: "It is enough that I am unfortunate, which allows me the right to your protection."

${ }^{12}$ He was well-known as a man of slovenly and unkempt appearance. Reports of the scene at his death suggest he lived in squalor rather than dignified poverty. He sat in a peculiar shoe-shaped tub that was "nearly black from dirt", without the pressed sheets and blankets which David highlights. His head was not wrapped in an antiseptic bandage, but "a napkin dripping vinegar that hung in the clotted masses of his heavy, greasy hair" (Louis Groarke, op. cil., p. 32). He was wearing a dirty birth robe around his shoulders and was surrounded by a pair of pistols, a placard with the word 'mort' ("death"), a dirty floor, pilaster wall paper and two plates of brains and sweetbreads.

${ }^{73}$ This is not, of course, the place to decide in any definitive way the truth about Marat's character, which is very much a source of controversy (for a relatively sympathetic view, see Louis $\mathrm{R}$. Gottschalk, Jean Paul Marat: A Study in Radicalism; Chicago: University of Chicago Press, 1967). Even those who adopt a more sympathetic view of him grant his excesses, however, and the historical record shows that David has fabricated many of the details of his painting.

${ }^{74}$ The reproduction below is a sketch by Jeff Cressman (copyright Leo Groarke 1997). For plates and discussion see, Walter L. Strauss, The Intaglio Prints of Albrecht Dürer (New York: Kennedy Galleries and Abaris Books, 1977), il. 62; Horst Michael, Albrecht Dürer: The Complete Engravings (New York: Artline Editions, 1984), 37; Charles W. Talbot, ed. Dürer in America: His Graphic Work (Washington: National Gallery of Art, 1971), il. 27; and Albrecht Durer: Master Printmaker (Boston: Museum of Fine Arts, 1988), il. 62. This engraving is often paired with "Coat of Ams with Lion and Rooster," which conveys a similar message (in visually significant ways that are, however, beyond the scope of the present paper).

${ }^{75}$ From Adbusters, Vol. 3, No. 4, Summer 1995, published by the Media Foundation, 1243 7th Avenue, Vancouver, B.C. V6H 1B7. Reprinted with permission.

${ }^{76}$ Combined with the images, these signatures 'advertise' the creativity and power of the works creators.

${ }^{77}$ But we should not expect a more complete theory of the visual to eliminate all the controversies that surround particular visual arguments. Informal logicians are notorious for their disagreements about the interpretation of particular arguments and we should expect such disagreements to characterize a discussion of visual examples. 
${ }^{78}$ See, e.g., Douglas N. Walton, Informal Logic: A Handbook for Critical Argumentation (New York: Cambridge University Press, 1989), esp. Ch. 1.

${ }^{79}$ See J. Anthony Blair, "Premise Adequacy," in van Eemeren et al, Analysis and Evaluation, Vol. II.

LEO GROARKE

DEPARTMENT OF PHILOSOPHY WILFRID LAURIER UNIVERSITY

WATERLOO, ONTARIO

CANADA N2L 3C5

LGROARKE@MACHI.WLU.CA

\section{กNกLOGín}

Revista de Filosofia.

ANALOGIA es una revista de investigación y difusión filosóficas del Centro de Estudios de la Provincia de Santiago de México de la Orden de Predicadores (Dominicos). ANALOGIA publica artículos de calidad sobre las distintas áreas de la filosofia.

Director: Mauricio Beuchot Consejo editorial: Ignacio Angelelli, Tomás Calvo, Roque Carrión, Gabriel Chico, Mareelo Dascal, Gabriel Ferrer, Jesús Garcia, Jorge J. E. Gracia, Klaus Hedwig; Angel Muñoz García, Ezequiel de Olaso, Lorenzo Peña, Livio Rosetti, Philibert Secretan, Enrique Villanueva, Luis Flores H.

Colaboraciones (articulos, notas, reseñas) y pagos enviarse a: Apartado postal 23-161

Xochimilco 16000 México, D.F.

MEXICO

Periodicidad semestral. Suscripción anual (2 números): 35 US dis. 